\title{
Studies on the properties of Celluclast/Eudragit L-100 conjugate
}

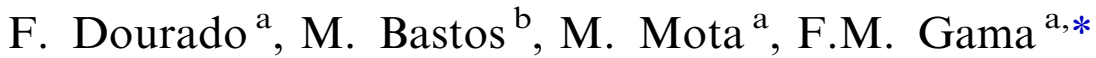 \\ ${ }^{a}$ Centro de Engenharia Biológica-IBQF, Largo do Paço, Universidade do Minho, 4719 Braga, Portugal \\ ${ }^{\mathrm{b}}$ Departamento de Química, CIQ(UP), FCUP, R. Campo Alegre, 687, P-4169-007 Porto, Portugal
}

Received 30 July 2001; received in revised form 13 December 2001; accepted 10 May 2002

\begin{abstract}
A cellulase from Trichoderma reesei was immobilized on Eudragit L-100, a reversibly soluble polymer depending on the $\mathrm{pH}$ of the medium. The solubility of the modified cellulase was studied at different $\mathrm{pH}$ values. By changing the $\mathrm{pH}$, the adsorption equilibrium of the derivatized proteins is switched towards the liquid phase, thus making recycling possible. This method allows for improved stability, without major loss of specific activity. The adsorption of cellulase on Eudragit lowers the enthalpy of denaturation, but affects only slightly the denaturation temperature. The use of carbodiimide was ineffective on linking the enzymes covalently to the polymer, since the immobilization process was found to be only mediated by non-covalent forces. (C) 2002 Elsevier Science B.V. All rights reserved.
\end{abstract}

Keywords: Cellulase; Carbodiimide; Eudragit L-100; Enzyme immobilization; DSC

\section{Introduction}

The use of industrial enzymes has gradually been extended in recent years to a variety of fields, such as food production, brewing, pharmaceuticals, medicine, textiles, and detergents. Among other enzymes, cellulases are well established in the textile industry as agents for fibre and fabrics modifications (Cavaco-Paulo et al., 1998; Campos et al., 2000). In the pulp and paper industry, cellulases also play an important role in the improvement of the properties of virgin and

\footnotetext{
* Corresponding author. Tel.: +351-253-605-419; fax: + 351-253-678-986

E-mail address: fmgama@deb.uminho.pt (F.M. Gama).
}

recycled fibers (Pommier et al., 1989; Sarkar et al., 1995; Pere et al., 1995). In the food industry, these enzymes have been used as processing aids in seed oil extraction (Domínguez et al., 1995; TanoDebrah and Ohta, 1995; Che Man et al., 1996). Conversion of lignocellulosic substrates from the food and paper industries with the help of cellulases has also been studied (Düsterhöft et al., 1993; Ramos et al., 1993; Béguin and Aubert, 1994; Duff et al., 1995).

The enzymes high specificity, nontoxicity, water solubility, biodegradability, and mild operational conditions of $\mathrm{pH}$, temperature, and pressure, are major advantages over inorganic catalysts (Taylor, 1991). In spite of these advantages, the use of enzymes in industrial applications has been limited because: (1) most enzymes are relatively unstable; 
(2) the costs of enzyme isolation and purification are still high; and (3) it is technically expensive to recover the active enzymes from the reaction mixture after completion of the catalytic process. To obviate some of these problems, the immobilization of enzymes has been studied extensively and nowadays, the use of immobilized enzymes has become well established.

Poor contact between the insoluble substrate and the immobilized enzyme as well as incomplete separation of the immobilized enzyme from unreacted solid substrates are common problems in heterogeneous reaction systems. Therefore, when enzymes are to be used with macromolecular or insoluble substrates, the immobilization of enzymes on soluble matrices is preferable over insoluble ones (Fujimura et al., 1987; Taniguchi et al., 1989, 1992). The covalent immobilization of enzymes, using carbodiimide and polymer carriers based on methacrylic acid and methyl methacrylate, has been studied for bioconversion processes (Fujimura et al., 1987; Taniguchi et al., 1989) and downstream processing (Kamihira et al., 1992; Guoqiang et al., 1993). These polymers can easily be made reversibly soluble-insoluble by changing the $\mathrm{pH}$, thus making possible the recycling of the enzymes.

In this work, the conjugation of Celluclast, a crude extract of Trichoderma reesei cellulases (Reese and Mandels, 1980; Béguin and Aubert, 1994), to Eudragit L-100 was studied. Eudragit L100 is the commercial name of an enteric polymer of methacrylic acid-methylmethacrylate that belongs to a class of reversible soluble/insoluble polymers (Fuji and Taniguchi, 1991).

\section{Materials and methods}

\subsection{Materials}

Celluclast 1.51 was kindly supplied by Novo, Denmark. Sigmacell 101, from Sigma, was used as substrate in the adsorption assays. A methacrylic acid-methylmethacrylate copolymer with a nominal molecular weight of $135 \mathrm{kDa}$, Eudragit L-100 (a commercial product from Rhöm Pharma, kindly provided by Degussa-Hüls, S.A., Barce- lona) was used as a reversible soluble/insoluble carrier for the immobilization of cellulase.

\subsection{Enzyme assay and protein concentration}

The activities of native and immobilized enzyme on filter paper were determined according to Mandels et al. (1976). Reducing sugars were determined by the dinitrosalicylic acid (DNS) method, using glucose as standard (Miller, 1959). Protein concentration was determined with a BioRad Protein Assay Kit, using bovine serum albumin (BSA) as standard.

The possible interference of the polymer in the estimation of the protein was analysed. For this purpose, standard solutions were prepared (BSA and BSA immobilized on Eudragit) with concentrations in the range of $0.1-1 \mathrm{mg} \mathrm{ml}^{-1}$, and the absorbance was determined. No significant changes in the absorbance values occurred when the polymer was present (data not shown).

\subsection{Immobilization method}

One gram of the polymer was dissolved in $50 \mathrm{ml}$ of $0.1 \mathrm{M}$ acetate buffer ( $\mathrm{pH}$ 5.5), at room temperature. A few drops of a commercial $\mathrm{NaOH}$ solution $\left(32 \mathrm{~g} 100 \mathrm{~g}^{-1}\right)$ were added to raise the $\mathrm{pH}$ to 8.0. Then, $0.3 \mathrm{~g}$ of 1-ethyl-3-(3dimethylaminopropyl)-carbodiimide hydrochloride (EDC) were dissolved in the buffer. In the work by Norde and Zoungrana (1998), the excess of EDC is removed before the addition of the enzyme by repeated precipitation and solubilization of the activated polymer. According to our experience, this process does not affect neither the amount of bound protein nor the activity of the conjugate (data not shown). Therefore, after stirring for $1 \mathrm{~h}$, the activated polymer was precipitated by lowering the $\mathrm{pH}$ to 3.5 , with $2 \mathrm{M}$ acetic acid. The polymer was then centrifuged (400 $\times g, 15 \mathrm{~min}$, room temperature), and washed three times with distilled water $(\mathrm{pH} 3.5)$. The activated polymer was then dispersed in $20 \mathrm{ml}$ of distilled water. A few drops of $\mathrm{NaOH}$ were added to adjust the $\mathrm{pH}$ of the mixture to 5.5, to solubilise the polymer, and the volume was brought to $25 \mathrm{ml}$ with distilled water. Finally, $25 \mathrm{ml}$ of $0.1 \mathrm{M}$ acetate 
buffer ( $\mathrm{pH}$ 5.5) were added, to complete the initial $50 \mathrm{ml}$ of the mixture.

Cellulase was added to the solution (50-1500 mg added Celluclast per $\mathrm{g}$ Eudragit). The mixture was left reacting for $6 \mathrm{~h}$, with continuous stirring, at room temperature. After this period, the $\mathrm{pH}$ of the mixture was reduced to 3.5 with $2 \mathrm{M}$ acetic acid, centrifuged $(400 \times g, 15 \mathrm{~min}$, room temperature) and washed three times with distilled water (at a $\mathrm{pH}$ of 3.5). The conjugate was finally dissolved in the same manner as described above for the activated polymer. The final solution was used as the Celluclast/Eudragit conjugate (E-C).

\section{4. $p H$ effect on the conjugate solubility}

The solubilities of Eudragit (E), Eudragit activated with carbodiimide (E+EDC), and of the conjugate (E-C), were assessed. To evaluate the effect of the amount of bound protein on the solubility of the conjugate, two different cellulase concentrations were tested: 100 and $500 \mathrm{mg}$ Celluclast per g Eudragit (E-C:100 and E-C:500). For both concentrations, the immobilization was done as described previously (at a $\mathrm{pH}$ of 5.5, for 6 h). The $\mathrm{pH}$ of the mixture was then reduced to 3.5 , and the conjugate was centrifuged and washed with distilled water. The conjugate was finally dissolved at a final $\mathrm{pH}$ of 7.5 (with $0.1 \mathrm{M}$ citrate buffer), in a similar manner as previously described for the adjustment of the standard $\mathrm{pH}$ (5.5).

This procedure was repeated for $\mathrm{E}$ and $\mathrm{E}+$ EDC, except no protein was added.

The $\mathrm{pH}$ of the mixture (for each of the four systems) was gradually reduced by addition of glacial acetic acid to the continuously stirred solution. Concentrated acid was used to avoid a significant variation of the initial volume.

The solubility was estimated by measuring the absorbance at $470 \mathrm{~nm}$, as reported by Margolin et al. (1985), and expressed as a ratio of absorbance at each $\mathrm{pH}$ tested, to the maximum value of the absorbance at a $\mathrm{pH}$ less than 3.5. Zero absorbance was set at the maximum solubility of the system.

\subsection{Adsorption properties of the conjugate}

To examine the degree of adsorption of native (C) and modified cellulase (E-C), both cellulase solutions were prepared at initial concentrations of $2 \mathrm{mg} \mathrm{ml}^{-1}$, at pH 5.5, in acetate buffer (for E-C, the immobilization was done as described in Section 2.3). Each cellulase (E and E-C), at various concentrations (in the range of $0.02-2 \mathrm{mg} \mathrm{ml}^{-1}$ final concentration), was mixed with Sigmacell 101

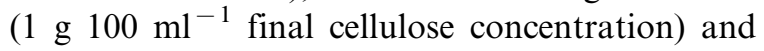
incubated at $50{ }^{\circ} \mathrm{C}$, for $30 \mathrm{~min}$, in $0.1 \mathrm{M}$ acetate buffer ( $\mathrm{pH}$ 5.5). After this period, the suspension was centrifuged $(400 \times g, 15 \mathrm{~min}$, room temperature) and the obtained supernatant was analysed for protein concentration. The amount of adsorbed protein was determined by subtracting the amount of protein in the supernatant from the initial concentration.

\subsection{Storage stability of modified cellulase}

The stabilities of $\mathrm{C}$ and $\mathrm{E}-\mathrm{C}$ were evaluated at $4{ }^{\circ} \mathrm{C}$, room temperature and $50{ }^{\circ} \mathrm{C}$. For this purpose, the activities of each cellulase, stored at different temperatures, was determined every 7 days, for a period of 3 weeks.

\subsection{Effect of salt on the conjugate activity and on protein desorption from Eudragit}

The effect of different salts (KSCN, $\mathrm{NaCl}, \mathrm{KCl}$, $\left.\left(\mathrm{NH}_{4}\right)_{2} \mathrm{SO}_{4}\right)$ on the removal of adsorbed protein, and on the recovery of the modified cellulase activity, was studied. For each tested salt, cellulase was first immobilized as described in Section 2.3. The initial protein content was determined. From a $3 \mathrm{M}$ salt solution, a determined volume was added to the mixture (final salt concentrations tested: $0.1,0.3,0.5$ and $1 \mathrm{M}$ ). After stirring for 30 $\mathrm{min}$ at room temperature, the conjugate was precipitated, centrifuged $(400 \times g, 15 \mathrm{~min}$, room temperature) and washed three times with distilled water (at a $\mathrm{pH}$ of 3.5). After solubilization, the protein content was determined. For each salt system (and for each salt concentration tested), three replicates were executed; after the second addition of salts, the mixture was stirred overnight; 
after the third addition, the mixture was stirred for $74 \mathrm{~h}$. A control was prepared without the addition of salt.

Celluclast was also immobilized in the presence of KSCN. After activation of the polymer with EDC, a determined volume of the salt solution (3 M) was added (final salt concentrations tested: 0.1, 0.3, 0.5 and $1 \mathrm{M})$. Celluclast was then added to the mixture. After stirring for $6 \mathrm{~h}$, at room temperature, the conjugate was precipitated, washed and dissolved as described in Section 2.3. Initial protein content and activity of the conjugate were then determined. For each tested concentration, this procedure was repeated up to six times. Protein and activity were determined after three and six precipitations.

\subsection{Size exclusion chromatography}

The following solutions were analysed by size exclusion chromatography: Eudragit L-100 (E), native $(\mathrm{C})$ and modified cellulase $(\mathrm{E}-\mathrm{C})$, before and following three (E-C:3) and six (E-C:6) precipitations. These assays were also done for cellulase immobilized with $300 \mathrm{mM} \mathrm{KSCN}$, before and following successive precipitations. In this case, precipitations were performed after the addition of $50 \mathrm{mM}$ KSCN.

The samples $(500 \mu \mathrm{l})$ were injected into a $9 \times 500$ mm Sephacryl S-400 HR packed column. Assays were run at a flow rate of $0.5 \mathrm{ml} \mathrm{min}{ }^{-1}$, at room temperature, using $50 \mathrm{mM}$ acetate buffer at a $\mathrm{pH}$ of 5.5 as eluent. The integrated absorbance signal between 220 and $280 \mathrm{~nm}$ was recorded, using a L7455 Diode-Array detector (Merk), and analysed with D-7000 HPLC System Manager (Version 3.1) software.

\subsection{Differential scanning calorimetry (MicroDSC)}

DSC runs were performed using a MicroDSC III from Setaram, France, using $1 \mathrm{ml}$ removable ampoules, charged with $0.8 \mathrm{ml}$ solution. The same volume of buffer was used on the reference ampoule. The runs were performed between 5 and $110{ }^{\circ} \mathrm{C}$, with a heating rate of $1 \mathrm{~K} \mathrm{~min}^{-1}$, with a constant flow of nitrogen through the instrument. In each experiment 2 successive upand down scans were performed, to investigate the reversibility of the denaturation process. All results were corrected for a blank experiment where the same volume $(0.8 \mathrm{ml})$ of buffer was used on both sides (measuring and reference side). The observed curves were integrated with the Setaram software, considering a linear baseline and a 3points integration, due to the superimposition of two peaks.

Repeated runs were performed with freshly prepared samples of native cellulase and cellulase immobilized with and without salt $(300 \mathrm{mM}$ KSCN) (before and following three and six successive precipitations). Some runs were also performed on solutions of Eudragit L-100, to see if some transition was apparent that would be only due to the polymer. The analyzed samples were previously dialysed at $4{ }^{\circ} \mathrm{C}$ against $50 \mathrm{mM}$ acetate buffer ( $\mathrm{pH}$ 5.5)

\section{Results and discussion}

\section{1. pH effect on the conjugate solubility}

The activation of carboxylic groups in the methacrylic acid-methylmetacrylate copolymer, using carbodiimide, leads to a shift towards more alkaline values in the solubility profile of Eudragit, as can be observed in Fig. 1 (E vs. E+EDC). Hence, the activated polymer becomes more hydrophobic. However, when protein is bound to the polymer (E-C:100 and E-C:500 mg Celluclast $\mathrm{g}^{-1}$ Eudragit), the solubility profile becomes similar to Eudragit's. It is possible that the hydrophilic character of the proteins render the conjugate more soluble when compared to $\mathrm{E}+$ EDC.

Differences in the protein/polymer ratio do not seem to induce significant changes in the solubility profile. This observation will be further discussed below. Kamihira et al. (1992) observed similar effects when varying the amount of $\mathrm{IgG}$ bound to Eudragit S-100. 


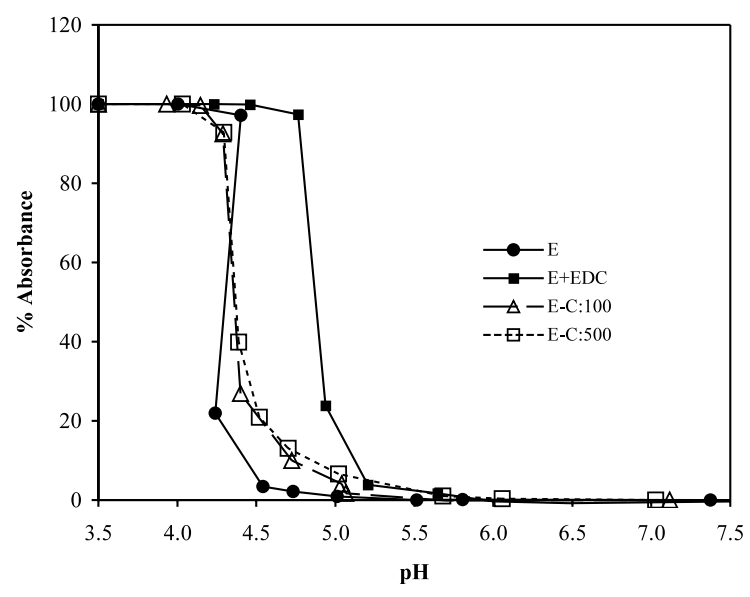

Fig. 1. Effect of $\mathrm{pH}$ on the solubility of Eudragit, before (E), and after the addition of EDC (E+EDC) and on immobilized Celluclast (E-C:100 and E-C:500). Each value is a mean of duplicate experiments. The difference in individual readings was less than $\pm 5 \%$.

\subsection{Preparation of immobilized cellulase}

Fig. 2 shows the amount of cellulase immobilized, and the recovery of specific activity relative to that of the native enzyme, when the enzyme concentration used in the immobilization process varies between 100 and $1600 \mathrm{mg}$ Celluclast $\mathrm{g}^{-1}$

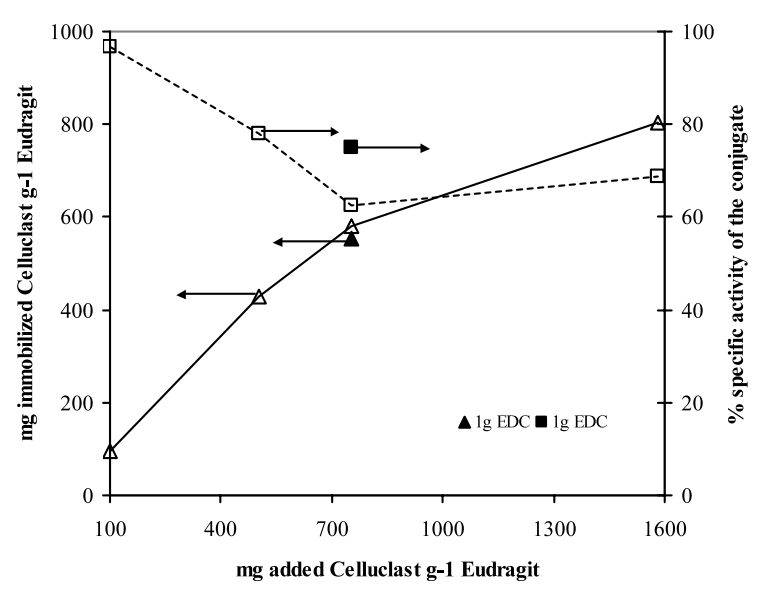

Fig. 2. Effect of the amount of cellulase added on the amount of immobilized cellulase and on the recovery of specific activity relative to that of the native enzyme. The solid symbols refer to immobilization using $1 \mathrm{~g}$ EDC (Carbodiimide) $\mathrm{g}^{-1} \mathrm{E}$ (Eudragit). In the standard assays, $0.3 \mathrm{~g}$ EDC was used. Each value is a mean of triplicate experiments. The difference in individual readings was less than $\pm 5 \%$.
Eudragit. In the range between 100 and $751 \mathrm{mg}$ Celluclast $\mathrm{g}^{-1}$ Eudragit, the amount of immobilized protein increases almost linearly with the solution concentration. However, another 2-fold increase in the protein relative concentration contributes only to a $38 \%$ increase in the amount of immobilized protein.

At a relative concentration of $100 \mathrm{mg}$ Celluclast $\mathrm{g}^{-1}$ Eudragit the recovery of specific activity, relative to that of the native enzyme, was at its maximum (97\%). As more protein was added, the activity decreased almost linearly to a minimum value of $63 \%$. This value seems to correspond to a plateau, since at a proportion of $1600 \mathrm{mg}$ Celluclast $\mathrm{g}^{-1}$ Eudragit, the amount of specific activity recovered was $69 \%$. The decrease in specific activity with an increase of bound protein can perhaps be attributed to the clustering of the immobilized protein molecules, which may avoid the approach of the macromolecular substrate to the enzyme active site. The clustering effect was previously observed by others, namely Norde and Zoungrana (1998), for cutinase adsorbed on silica, and Sardar et al. (2000) for xylanase adsorbed on Eudragit L-100. Alternatively, the preferential adsorption or binding of non-enzymatic proteins from the crude extract, may explain the decrease in the specific activity of the conjugate, with increasing protein concentration.

The molar ratio of immobilized Celluclast relative to Eudragit was estimated. Values between 0.21:1 and 1.81:1 (Celluclast:Eudragit) were obtained, corresponding to protein concentrations between 100 and $1600 \mathrm{mg}$ added Celluclast $\mathrm{g}^{-1}$ Eudragit. These results show that for the lower enzyme/polymer ratios, some polymer molecules have no bound protein. This observation may explain why, despite a 5-fold increase in the amount of added protein (E-C:100 vs. E-C:500), the solubility profile (Fig. 1) is not significantly changed, as at those relative concentrations the molar ratio is smaller than one. It confirms also the referred clustering effect: the enzyme specific activity is lower when the molar ratio (enzyme:polymer) goes beyond 1 .

As will be shown later, Celluclast is bound to Eudragit mainly by non-specific forces. Even when only $100 \mathrm{mg}$ Celluclast $\mathrm{g}^{-1}$ Eudragit is added to 
the activated polymer, $14 \%$ of the modified protein was removed, after three successive precipitations. As the amount of protein added (and therefore immobilized on to Eudragit) increased, more protein was removed, following successive precipitations (data not shown). Taniguchi et al. (1992) reported a similar effect of protein removal off the conjugate following several precipitations of modified Meicelase.

In the standard method for protein immobilization (see Section 2.3), the mass ratio of carbodiimide relative to Eudragit is $0.3: 1$. To verify if more protein could be covalently bound to the polymer, the mass ratio of EDC relative to Eudragit was increased to 1:1, rendering approximately $1 \mathrm{~mol}$ of EDC $\mathrm{mol}^{-1}$ of Eudragit carboxylic groups. However (Fig. 2), despite the increase in specific activity, a similar amount of immobilized protein was obtained.

\subsection{Adsorption properties}

To compare the adsorption of native and modified Celluclast, the amount of protein adsorbed per gram of Sigmacell 101 was examined as a function of Celluclast concentration. Fig. 3 shows the adsorption isotherms for these situa-

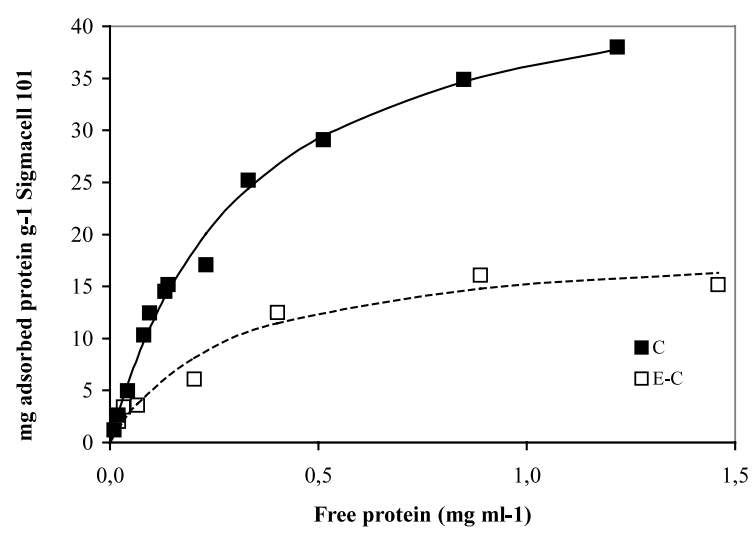

Fig. 3. Adsorption isotherms of the native (C) and modified Celluclast (E-C). The continuous line was calculated by using $P_{\text {ads, } \mathrm{m}}=47.6 \mathrm{mg}$ protein $\mathrm{g}^{-1}$ Sigmacell 101 and $K=3.2 \mathrm{ml} \mathrm{g}^{-1}$ Sigmacell 101 for the native Celluclast; broken line was calculated by using $P_{\text {ads, } \mathrm{m}}=19.4 \mathrm{mg}$ protein $\mathrm{g}^{-1}$ Sigmacell 101 and $K=3.6 \mathrm{ml} \mathrm{g}^{-1}$ Sigmacell 101 for the immobilized Celluclast. Each value is a mean of six experiments. The difference in individual readings was less than $\pm 5 \%$. tions. As observed from this figure, data on the adsorption isotherms fitted to the Langmuir equation:

$P_{\text {ads }}=\frac{K \times P_{\text {ads }, \mathrm{m}} \times P}{1+K \times P}$

where $P_{\text {ads }}$ is the adsorbed protein in mg protein $\mathrm{g}^{-1}$ cellulose, $K$ is the apparent adsorption equilibrium constant ( $\mathrm{ml} \mathrm{mg}^{-1}$ protein), $P_{\text {ads,m }}$ is the maximum amount of adsorbed protein $(\mathrm{mg}$ protein $\mathrm{mg}^{-1}$ cellulose) and $P$ is the protein concentration in the supernatant $(\mathrm{mg}$ protein $\mathrm{ml}^{-1}$ ).

Immobilization of Celluclast caused a $60 \%$ decrease in $P_{\text {ads, } m}$, whereas $K$ values remained almost the same. These results show that the modified enzyme has the same affinity as the native one to the substrate, but the maximum amount of adsorbed enzyme is strongly reduced. This fact can be due to the referred clustering effect that could cause a lower accessibility to the Sigmacell surface. On the other hand, the immobilized enzyme has probably more spatial restriction, which could also be difficult for adsorption. The reduced modified cellulases adsorption on solid substrates was also observed by Taniguchi et al. (1989) and by Park and Kajiuchi (1995).

\subsection{Storage stability of modified cellulase}

The stability of native (C) and modified cellulase (E-C) was evaluated at $4{ }^{\circ} \mathrm{C}$, room temperature and $50{ }^{\circ} \mathrm{C}$ (Fig. 4). At $4{ }^{\circ} \mathrm{C}$ and room temperature, the modified enzyme virtually retained the initial specific activity for 14 days. After an additional 7-day period, a decrease of $12 \%$ occurred at $4{ }^{\circ} \mathrm{C}$, and a $36 \%$ decrease at room temperature.

At $50{ }^{\circ} \mathrm{C}$, the activity profile of native Celluclast is similar to that of the modified one. Major differences are noticeable at $4{ }^{\circ} \mathrm{C}$ and room temperature, where native Celluclast showed an almost linear decrease in specific activity. After 21 days, $63 \%$ of the initial cellulase activity was lost at $4{ }^{\circ} \mathrm{C}$, and at room temperature, $81 \%$ was lost. Thus, modification of Celluclast with Eudragit improves the stability of the enzyme, with minor 


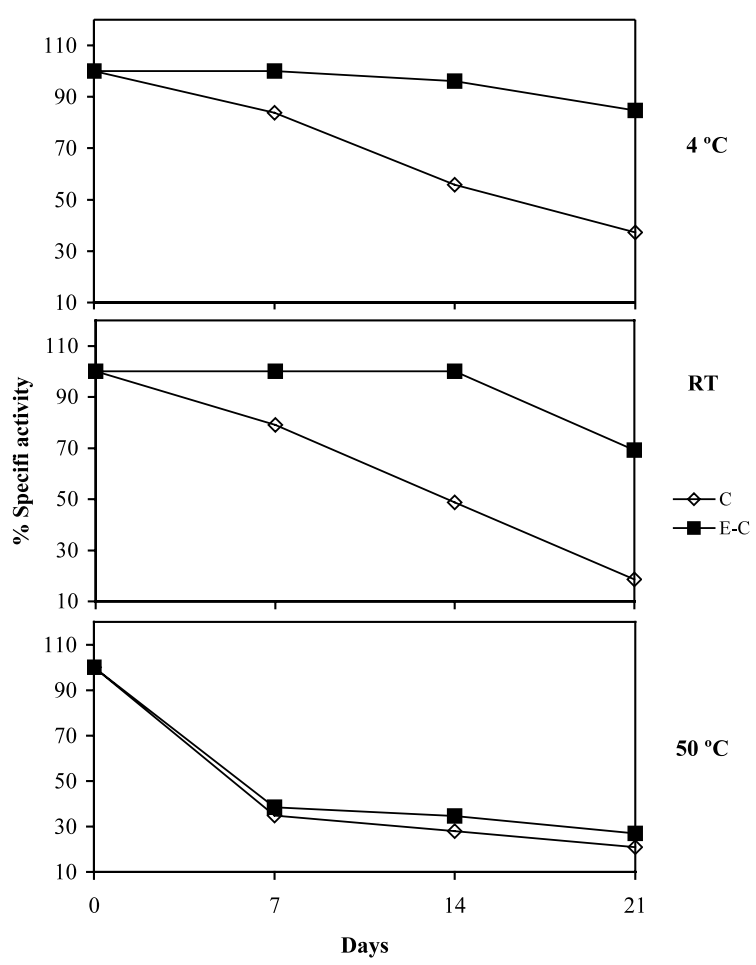

Fig. 4. Thermal stability of native (C) and modified Celluclast (E-C) at $4{ }^{\circ} \mathrm{C}$, room temperature (RT) and $50{ }^{\circ} \mathrm{C}$. The initial specific activity of $\mathrm{C}$ and $\mathrm{E}-\mathrm{C}$ were taken as $100 \%$. Each value is a mean of duplicate experiments. The difference in individual readings was less than $\pm 5 \%$.

loss of specific activity. At $4{ }^{\circ} \mathrm{C}$ and at room temperature, the specific activity loss is much smaller for the modified enzyme than for the native one. The significant and similar lowering of activity for $\mathrm{E}$ and $\mathrm{E}-\mathrm{C}$ at $50{ }^{\circ} \mathrm{C}$ is probably due to a significant denaturation at this temperature for both enzymes, as the denaturation temperature is in both cases close to this temperature (see DCS results, Table 3). This fact can explain why in this case, where the inactivation was mainly caused by temperature, both systems present a similar behaviour.

\subsection{Effect of salt on the conjugate activity and on protein desorption from Eudragit}

It has been observed that some proteins adsorb non-specifically to Eudragit polymers (Guoqiang et al., 1993; Shu et al., 1994; Sardar et al., 1997;
Tyagi et al., 1998; Arasaratnam et al., 2000; Sardar et al., 2000). Different salts and surfactants remove protein non-covalently bound to these polymers (Guoqiang et al., 1993; Shu et al., 1994; Tyagi et al., 1998; Arasaratnam et al., 2000). The effect of the addition of several salts in the removal of protein adsorbed on Eudragit was therefore assessed.

From an initial solution of modified cellulase (363.5 mg bound protein $\mathrm{g}^{-1}$ Eudragit), KSCN was found to remove the greatest amount of adsorbed protein. In addition, the higher the molarity of $\mathrm{KSCN}$, the higher the protein desorption from Eudragit (data not shown). Therefore, to investigate the best $\mathrm{KSCN}$ concentration that would minimize the amount of protein adsorbed onto Eudragit, with minimum loss of activity of the conjugate, Celluclast was immobilized (381.5 $\mathrm{mg}$ added Celluclast $\mathrm{g}^{-1}$ Eudragit) in the presence of $0.1,0.3,0.5$ and $1 \mathrm{M}$ of KSCN. After immobilization, the conjugates were precipitated up to six times. Before each precipitation step, the above solutions of $\mathrm{KSCN}$ were added to the mixture. It was found that (Table 1) the immobilization of Celluclast with $1 \mathrm{M} \mathrm{KSCN}$ allowed for the smallest amount of protein adsorption and the enzyme was mostly inactivated. For 0.3 and $0.5 \mathrm{M}$, the conjugate lost its enzymatic activity after three precipitations. When Celluclast was immobilized in the presence of $0.1 \mathrm{M}$, after six precipitation steps, the conjugate retained only $32 \%$ of its initial activity.

It is possible that the high salt concentrations contribute to the enzyme denaturation. For lower salt concentrations, gradual enzyme denaturation may also occur, following the successive precipitations. Considering these results, the immobilization in the presence of $0.3 \mathrm{M} \mathrm{KSCN}$ was tested, and the conjugate was precipitated up to six times, following the addition of $50 \mathrm{mM} \mathrm{KSCN}$ to allow for the removal of adsorbed protein, while minimizing the loss of specific activity. The results from these experiments are shown in Table 2. When compared to a control without the addition of salt, after six precipitations, the modified cellulase KSCN-II showed higher specific activity. However, another observation must be pointed out. When the initial specific activity of the 
Table 1

Effect of KSCN concentration on the amount of bound Celluclast and on specific activity of the conjugate

\begin{tabular}{|c|c|c|c|c|c|c|}
\hline \multirow[t]{2}{*}{$\mathrm{KSCN}(\mathrm{M})$} & \multicolumn{3}{|c|}{$\begin{array}{l}\mathrm{mg} \text { bound Celluclast } \mathrm{g}^{-1} \text { Eudragit } \\
\text { No. precipitations }\end{array}$} & \multicolumn{3}{|c|}{$\%$ specific activity $^{\mathrm{a}}$} \\
\hline & 0 & 3 & 6 & 0 & 3 & 6 \\
\hline 0.1 & 305.5 & 149.5 & 115 & 100 & 77 & 32 \\
\hline 0.3 & 223.5 & 48.5 & - & 100 & 0 & - \\
\hline 0.5 & 216 & 53.5 & - & 100 & 0 & - \\
\hline 1 & 201.5 & - & - & 0 & - & - \\
\hline
\end{tabular}

a The initial specific activity of each conjugate was taken as $100 \%$.

Each value is a mean of duplicate experiments. The difference in individual readings was less than $\pm 5 \%$.

Table 2

Recovery of specific activity of immobilized Celluclast with 0.3 M KSCN, following successive precipitations with $50 \mathrm{mM}$ $\mathrm{KSCN}$

\begin{tabular}{llcc}
\hline No. precipitations & Control $^{\mathrm{a}}$ & KSCN-I $^{\mathrm{b}}$ & KSCN-II $^{\mathrm{b}}$ \\
\cline { 2 - 4 } & $\begin{array}{l}\text { \% activity } \\
\text { (relative to the activity of native enzyme) }\end{array}$ \\
\hline 0 & 63 & 96 & 50 \\
3 & 59 & 31 & 50 \\
6 & 6 & 31 & 35 \\
& mg bound Celluclast $\mathrm{g}^{-1}$ & Eudragit \\
0 & 579.5 & 222 & 246 \\
3 & 255.5 & 133 & 130 \\
6 & 242 & 90.5 & 94 \\
\hline
\end{tabular}

a Control: $750 \mathrm{mg}$ Celluclast $\mathrm{g}^{-1}$ Eudragit of Celluclast was added.

b Celluclast was immobilized in the presence of $0.3 \mathrm{M}$ KSCN. Before each precipitation step, $50 \mathrm{mM} \mathrm{KSCN}$ was added. In KSCN-I assays, $503.5 \mathrm{mg}$ Celluclast $\mathrm{g}^{-1}$ Eudragit was added; in KSCN-II assays, $381.5 \mathrm{mg}$ Celluclast $\mathrm{g}^{-1}$ Eudragit was added.

Each value is a mean of duplicate experiments. The difference in individual readings was less than $\pm 5 \%$.

conjugate immobilized with salt was high $(96 \%$; KSCN-I), after three precipitations the activity was reduced by $65 \%$. This activity was maintained after three additional precipitations. The initial activity of KSCN-II was $50 \%$ of that of the native enzyme, and the immobilized cellulase lost an additional $15 \%$ of activity only after six precipitations.

Table 2 shows that the addition of salt allows further protein desorption, between the third and sixth precipitation. On the other hand, the addition of KSCN avoids the formation of aggregates, which becomes visually noticeable after several precipitation stages in the control assays. An attempt to explain this observation is as follows: when the amount of protein in the conjugate is high, the clustering of the protein molecules may prevent the interaction among the conjugate molecules, due to steric hindrance. However, for the Control group, as more protein is desorbed during successive precipitations, the remaining bound protein cross-links the polymer molecules. The addition of salt appears to prevent this phenomenon.

\subsection{Studies on the protein-polymer interactions}

The modified cellulases were analysed by size exclusion chromatography, in order to verify whether the formation of above-mentioned macromolecular aggregates is detectable (and measurable) in the early stage of formation. Also, we aimed at quantifying the percentage of conjugated polymer molecules, and the conjugation stoichiometry. The obtained chromatographic profiles are shown in Fig. 5. The analysed immobilized enzyme was obtained with no salt either in the immobilization and precipitations processes (similar chromatograms were obtained for Celluclast immobilized with $300 \mathrm{mM} \mathrm{KSCN}$ and precipitated up to six times with $50 \mathrm{mM} \mathrm{KSCN}$ ).

The chromatographic profiles of the bioconjugates (cellulase/polymer) seem to be a composition of pure Eudragit and cellulase molecules, and no 

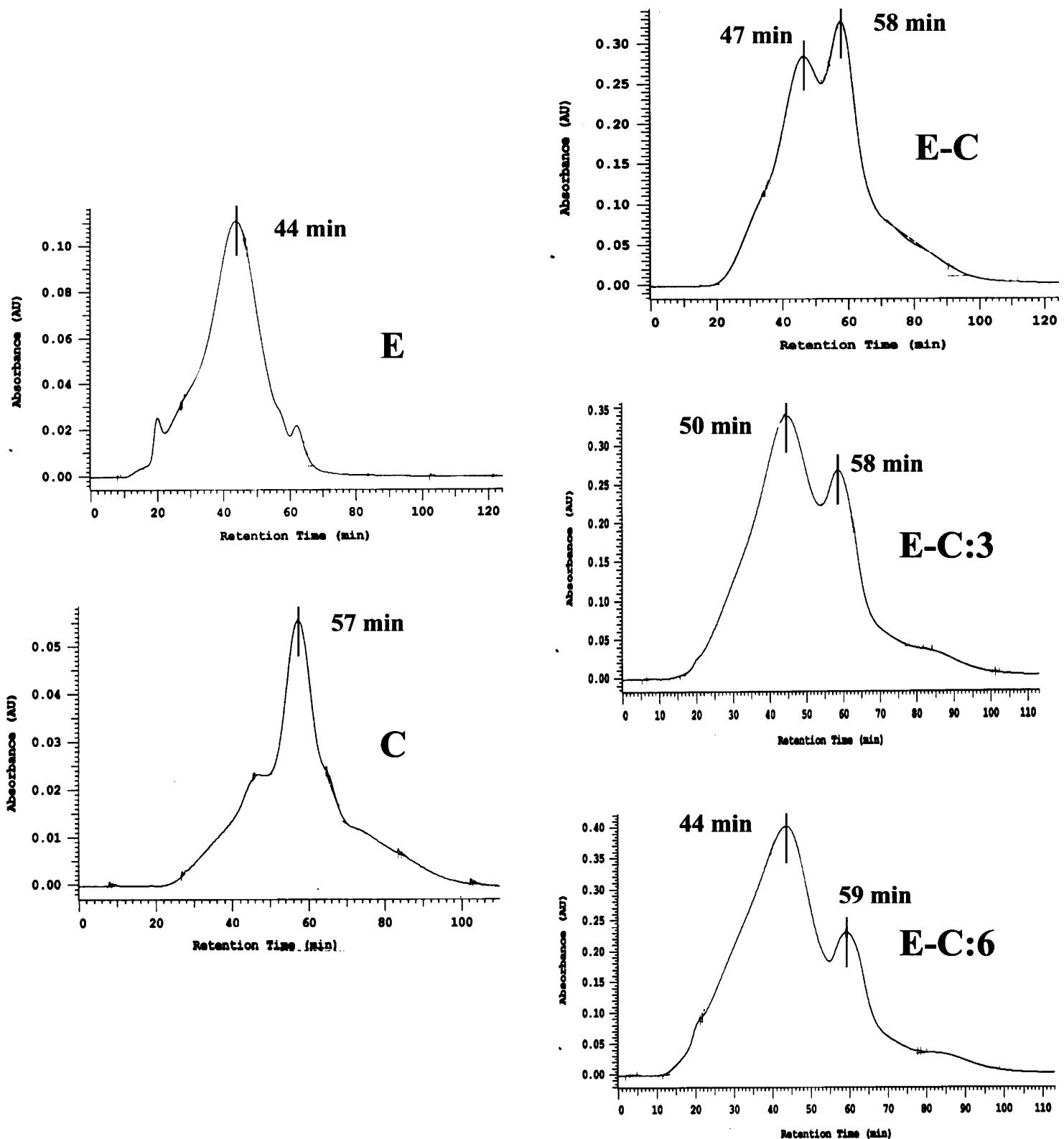

Fig. 5. Sample chromatograms of Eudragit (E), native Celluclast (C), modified Celluclast, before (E-C) and following three (E-C:3) and six (E-C:6) precipitations.

detectable molecules in the range of $200 \mathrm{kDa}$ (Eudragit + cellulase) were observed. Two peaks were recorded for the modified cellulase (both before and following the precipitations), suggesting that some of the protein adsorbed to Eudragit was desorbed from the polymer as the injected sample passed through the column. As a matter of fact, the low molecular weight peak has a retention time comparable to the native enzyme (57 $\mathrm{min}$ ), and the high molecular weight one has a retention time similar to that of Eudragit (44 min). This observation suggests that the amount of protein 
bound covalently to the polymer is very small. It also shows that the intermolecular forces that bind the protein to the polymer are very weak.

In the DSC studies, we observed that the overall specific enthalpy of denaturation (in $\mathrm{J} \mathrm{g}^{-1}$ protein) of the immobilized enzyme is in all cases smaller than that of the native one (Table 3). Further, it decreases as the number of precipitations increases, the effect being more pronounced when Celluclast was immobilized in the presence of $\mathrm{KCN}$. In all samples (native, Control and $\mathrm{KSCN}$ ), two distinct endothermic peaks were recorded (Fig. 6) (the DSC runs with Eudragit produced no peak over the all temperature range), and the transitions were not reversible. The contribution of peak $2\left(\% \Delta H_{2}\right)$ to the total enthalpy increased with the number of precipitations. Sardar et al. (2000) obtained a cellulase-free xylanase preparation by adsorbing Pectinex ${ }^{\mathrm{TM}} 3 \mathrm{XL}$ on Eudragit L-100, which suggests that the cellulolytic components of Celluclast have a variable strength of adsorption. Hence, the preferential desorption of some components, following the precipitations, may explain the decrease of $\% \Delta H_{1}$, suggesting that the proteins associated to the first transition have a higher specific denaturation enthalpy.

The denaturation temperatures of the modified enzyme, on the other hand, did not change. This shows that the immobilized enzyme is as stable as the native one to temperature denaturation.

This work shows that the interaction between cellulases and Eudragit, even in the presence of

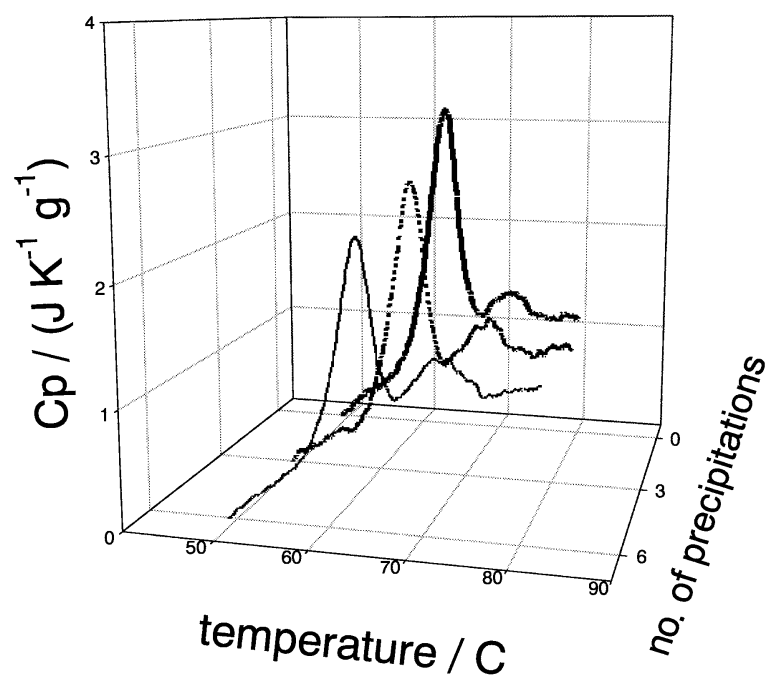

Fig. 6. Excess heat capacity vs. temperature curves at the denaturation temperature range for the immobilized enzyme, where the two peaks corresponding to $\Delta H_{1}$ and $\Delta H_{2}$ can be clearly seen. Bold black line, before precipitation; dotted line, after three precipitation cycles; thin black line, after six precipitation cycles.

carbodiimide, is essentially non-covalent. This is at present a major limitation in the application of the reversibly soluble polymers for enzyme immobilization. Since and increased stability of the modified enzyme over time was observed, further work will focus on the development of a suitable methodology for the production of a more stable bioconjugate, in order to avoid the significant losses on recovery by precipitation that were observed here.

Table 3

Specific enthalpy of protein denaturation for native and modified Celluclast, before (0) and following three (3) and six (6) precipitations

\begin{tabular}{|c|c|c|c|c|c|c|}
\hline Sample & & Peak $1\left({ }^{\circ} \mathrm{C}\right)$ & Peak $2\left({ }^{\circ} \mathrm{C}\right)$ & $\Delta H_{1}(\%)$ & $\Delta H_{2}(\%)$ & Total $\Delta H\left(\mathrm{~J} \mathrm{~g}^{-1}\right.$ protein $)$ \\
\hline \multirow[t]{2}{*}{ Native } & & 62.8 & 69.7 & 94 & 6 & 15.5 \\
\hline & 0 & 62.8 & 70.6 & 87 & 13 & 13.1 \\
\hline \multirow[t]{3}{*}{ Control $^{\mathrm{a}}$} & 3 & 63.5 & 72.3 & 81 & 19 & 11.5 \\
\hline & 6 & 63.1 & 71.3 & 73 & 26 & 9.2 \\
\hline & 0 & 62.6 & 70.8 & 82 & 18 & 12.6 \\
\hline \multirow[t]{2}{*}{$\mathrm{KSCN}^{\mathrm{b}}$} & 3 & 62.9 & 71.7 & 74 & 26 & 9.8 \\
\hline & 6 & 63.7 & 71.3 & 68 & 32 & 7.6 \\
\hline
\end{tabular}

a Control refers to Celluclast immobilized and precipitated without salt.

${ }^{\mathrm{b}}$ Celluclast was immobilized in the presence of $0.3 \mathrm{M} \mathrm{KSCN}$. Before each precipitation step, $50 \mathrm{mM}$ KSCN was added.

Each value is a mean of triplicate experiments. The difference in individual readings was less than $\pm 5 \%$. 


\section{Acknowledgements}

This work was funded by INCO-DC (96-2205) programme (OLONOCO). The authors would like to acknowledge the financial support from FCT to Centro de Investigação em Química (CIQ/UP), linha 5, Unidade de Investigação 81.

\section{References}

Arasaratnam, V., Galaev, I.Y., Mattiasson, B., 2000. Reversibly soluble biocatalyst: optimization of trypsin coupling to Eudragit S-100 and biocatalyst activity in soluble and precipitated forms. Enzyme Microb. Technol. 27, 254-263.

Béguin, P., Aubert, J.-P., 1994. The biological degradation of cellulose. FEMS Microbiol. Rev. 13, 25-58.

Cavaco-Paulo, A., Almeida, L., Bishop, D., 1998. Hydrolysis of cotton cellulose by engineered cellulases from Trichoderma reesei. Textile Res. J. 68 (4), 273-280.

Campos, R., Cavaco-Paulo, A., Andreaus, J., Gübitz, G., 2000. Indigo-cellulase interactions. Textile Res. J. 70 (6), 532-536.

Che Man, Y.B., Suhardiyono, A.B., Asbi, A.B., Azudin, M.N., Wei, L.S., 1996. Aqueous enzymatic extraction of coconut oil. J. Am. Oil Chem. Soc. 73 (6), 683-686.

Domínguez, H., Núñez, M.J., Lema, J.M., 1995. Enzymeassisted hexane extraction of soy bean oil. Food Chem. 54, $223-231$.

Duff, S.J.B., Woritz, J.W., Casavant, T.E., 1995. Effect of surfactant and particle size reduction on hydrolysis of deinking sludge and nonrecyclable newsprint. Biotechnol. Bioeng. 45, 239-244.

Düsterhöft, E.-M., Engels, F.M., Voragen, A.G.J., 1993. Parameters affecting the enzymic hydrolysis of oil-seed meals, lignocellulosic by-products of the food industry. Biores. Technol. 44, 39-46.

Fuji, M., Taniguchi, M., 1991. Application of reversibly soluble polymers in bioprocessing. Trends Biotechnol. 9, 191-196.

Fujimura, M., Mori, T., Tosa, T., 1987. Preparation and properties of soluble-insoluble immobilized proteases. Biotechnol. Bioeng. 29, 747-752.

Guoqiang, D., Kaul, R., Mattiasson, B., 1993. Purification of Lactobacillus bulcaricus D-lactase dehydrogenase by precipitation with an anionic polymer. Bioseparation 3, 333341.

Kamihira, M., Kaul, R., Mattiasson, B., 1992. Purification of recombinant protein A by aqueous two-phase extraction integrated with affinity precipitation. Biotechnol. Bioeng. 40, 1381-1387.

Mandels, M., Andreotti, R., Roche, C., 1976. Measurement of saccharifying cellulase. Biotechnol. Bioeng. Symp. 6, 21-33.

Margolin, A.L., Sherstyuk, S.F., Izumrudov, V.A., Zezin, A.B., Kabanov, V.A., 1985. Enzymes in polyelectrolyte complexes. The effect of phase transition on thermal stability. Eur. J. Biochem. 146, 625-632.
Miller, G.L., 1959. Use of dinitrosalicylic acid reagent for determination of reducing sugar. Anal. Chem. 31, 426428.

Norde, W., Zoungrana, T., 1998. Surface-induced changes in the structure and activity of enzymes physically immobilized at solid/liquid interfaces. Biotechol. Appl. Biochem. 28, $133-143$.

Park, J.W., Kajiuchi, T., 1995. Development of effective modified cellulase for cellulose hydrolysis process. Biotechnol. Bioeng. 45, 366-373.

Pere, J., Siika-aho, M., Buchert, J., Viikari, L., 1995. Effects of purified Trichoderma reesei cellulases on the fiber properties of kraft pulp. Tappi J. 78 (6), 71-78.

Pommier, J.-C., Fuentes, J.-L., Goma, G., 1989. Using enzymes to improve the process and the product quality in the recycled paper industry Part 1: the basic laboratory work. Tappi J. 72 (6), 187-190.

Ramos, L.P., Nazhad, M.M., Saddler, J.N., 1993. Effect of enzymatic hydrolysis on the morphology and fine structure of pretreated cellulosic residues. Enzyme Microb. Technol. $15,821-831$.

Reese, E.T., Mandels, M., 1980. Stability of the cellulase of Trichoderma reesei under use conditions. Biotechnol. Bioeng. 22, 323-335.

Sardar, M., Agarwal, R., Kumar, A., Gupta, M.N., 1997. Noncovalent immobilization of enzymes on an enteric polymer Eudragit S-100. Enzyme Microb. Technol. 20, $361-367$.

Sardar, M., Ipsita, R., Gupta, N., 2000. Simultaneous purification and immobilization of Aspergillus niger xylanase on the reversible soluble polymer Eudragit ${ }^{\mathrm{TM}}$ L-100. Enzyme Microb. Technol. 27, 672-679.

Sarkar, J.M., Cosper, D.R., Harting, E.J., 1995. Applying enzymes and polymers to enhance the freeness of recycled fiber. Tappi J. 78 (2), 89-95.

Shu, H.-C., Guoqiang, D., Kaul, R., Mattiasson, B., 1994. Purification of the D-Lactate dehydrogenase from Leuconostoc mesenteroides ssp. cremoris using a sequential precipitation procedure. J. Biotechnol. 34, 1-11.

Taniguchi, M., Kobayashi, M., Fujii, M., 1989. Properties of a reversible soluble-insoluble cellulase and its application to repeated hydrolysis of crystalline cellulose. Biotechnol. Bioeng. 34, 1092-1097.

Taniguchi, M., Hoshino, K., Watanable, K., Sugai, K., Fujii, M., 1992. Production of soluble sugar from cellulosic materials by repeated use of a reversibly soluble-autoprecipitating cellulase. Biotechnol. Bioeng. 39, 287-292.

Tano-Debrah, K., Ohta, Y., 1995. Enzyme-assisted aqueous extraction of shea fat: a rural approach. J. Am. Oil Chem. Soc. 72 (2), 251-256.

Taylor, R.E., 1991. Protein Immobilization. Fundamentals and Applications. Marcel Dekker, New York, p. 2.

Tyagi, R., Roy, I., Agarwal, R., Gupta, M.N., 1998. Carbodiimide coupling of enzymes to the reversibly soluble insoluble polymer Eudragit S-100. Biotechnol. Appl. Biochem. 28, 201-206. 